\title{
Impact of State Institutions on the Quality of Accounting Practice in Nigeria
}

\author{
Iyoha Francis Odianonsen, Ojeka Stephen and Ajayi Anijesu \\ Department of Accounting, Covenant University, Ota, Ogun State, Nigeria
}

Correspondence should be addressed to: Iyoha Francis Odianonsen; iyohafrancis@yahoo.co.uk

Received date: 21 September 2013; Accepted date: 13 January 2014; Published date: 31 December 2014

Copyright @ 2014. Iyoha Francis Odianonsen, Ojeka Stephen and Ajayi Anijesu. Distributed under Creative Commons CC-BY 3.0

\begin{abstract}
Although institutions play significant roles in ensuring a high quality of accounting practice, their impact is not well understood in the context of Nigeria. Drawing on the perception of users and compliers of accounting information, this study empirically investigates the impact of state institutions on the quality of accounting practice in Nigeria. The results of this study, using multiple regression analysis, indicate the impact of state institutions on the quality of accounting practice in Nigeria is fairly significant. Though joint significance was observed, however, the level of impact differs among the institutions. This implies that regulations are not adequate in ensuring a high level quality of accounting practice in Nigeria. These findings provide support for the need to streamline, strengthen and harmonize existing regulatory arrangements in Nigeria with a view to codifying as separate laws to enhance their effectiveness. Thus, inconsistencies in the provisions of the institutions and differences in the assessment of the quality of accounting practice by the relevant bodies would be minimised and monitoring and enforcement of regulations enhanced.
\end{abstract}

Keywords: Institutions, Quality of Accounting, Relevance, Reliability

\section{Introduction}

The quality of accounting practice is a fundamental requirement for users who require accounting information that is useful for investment and other similar decision making tasks. This is also true at the macro level where the government at various levels requires accounting information for the management of the economy. When the information generated represents the "economic substance" of an organization, then accounting practice is regarded as useful in terms of relevance, reliability and comparability (Spiceland, Sepe and Tomassini (2001:36). This has not been the case in Nigeria where the World Bank and others that have interest in financial reporting have criticized the country for suffering from poor institutional weaknesses in regulation, compliance and enforcement of accounting standards and rules (Okike,

Cite this Article as: Iyoha Francis Odianonsen, Ojeka Stephen and Ajayi Anijesu (2014)," Impact of State Institutions on the Quality of Accounting Practice in Nigeria", Journal of South African Business Research, Vol. 2014 (2014), Article ID 782177, DOI: 10.5171/2014.782177 
2004) and thus, does not meet the required quality.

The criticisms became pronounced due to the series of corporate failures involving banks in Nigeria in the mid 1980s to early 1990s following the deregulation of the Nigerian economy. These incidents brought accounting practice into sharp focus. The incidents and criticisms have persisted even though there are quite a number of regulatory bodies whose provisions directly affect the practice of accounting. It is in recognition of these criticisms, as noted by Iyoha and Jimoh (2011) that Nigeria officially adopted the International Financial Reporting Standards (IFRS) in 2012.

Therefore, the objective of this study is to contribute to the current discourse in this area by exploring the question of whether Nigeria has the required and relevant state agencies to support the quality of accounting practice needed by stakeholders. Our findings should assist relevant stakeholders to understand how state agencies impact the quality of financial reporting in Nigeria.

Following the preceding discussions, the rest of this paper is structured as follows: The institutional and legal requirements for financial reporting in Nigeria are described in section 2, while Section 3 is a review of related literature and development of hypothesis. The data and methodology used in this study are described in section 4 and Section 5 reports the result of the study. Finally, Section 6 contains the conclusion and recommendations.

\section{The Context of Financial Reporting in Nigeria}

In Nigeria, there are several bodies whose regulatory activities affect accounting practice. However, the Companies and Allied Matters Act, CAP (20), LFN (2004) is the main legal framework for accounting practice. It is required by virtue of the provisions of the Act that financial statements of companies in Nigeria comply with the requirements of the various agencies to guide the preparation of financial statements. This is important in order to reduce differences in accounting practice in the country. The table below shows the enabling instruments and the relevant agencies charged with regulating accounting practice in Nigeria.

Table 1: Enabling Instruments and Institutions

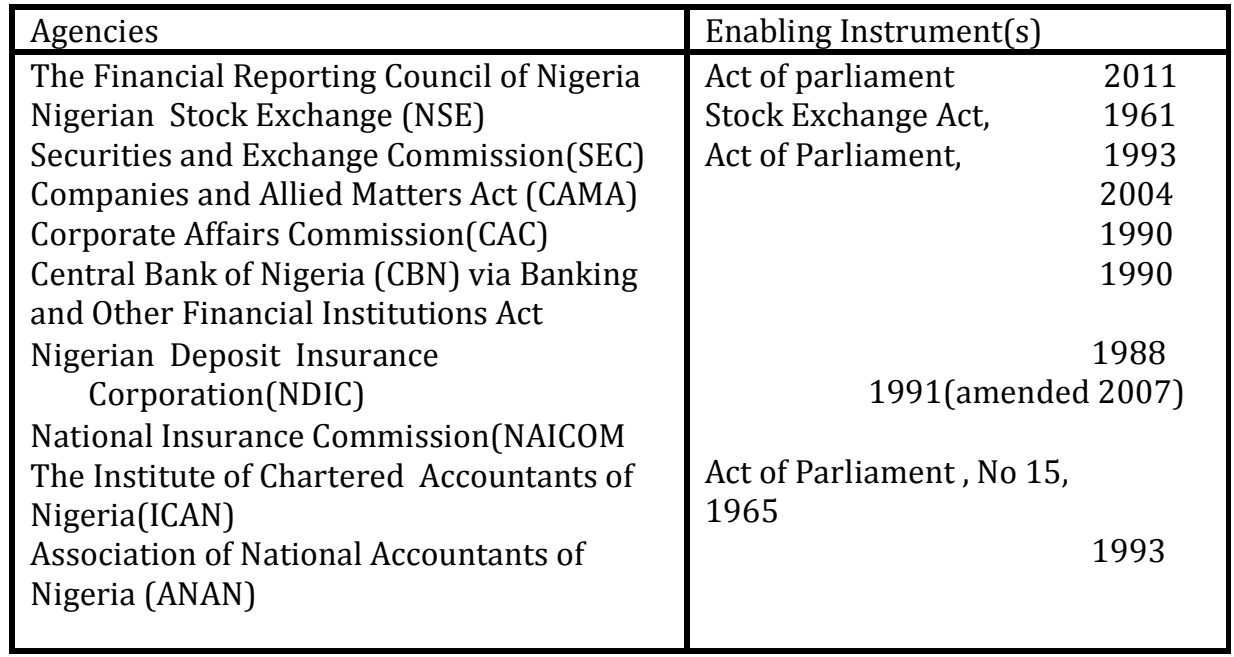




\section{Literature Review and Development of Hypothesis}

The main objective of accounting is to provide information to interested parties to make complete, timely and reliable economic decisions. Sometimes, the information could be asymmetric and unreliable. This situation of information asymmetry is often used to justify the need for accounting regulation by the state. Sometimes, the regulation extends well beyond the information to the preparers of such information. Consequently, accounting and accountants are now subject to a wide range of regulations exercised by state agencies and related bodies. According to Uche (2002: 472), the state has a significant role in developing accounting practice and this is "more prominent in a developing country like Nigeria without a welldeveloped political culture." $\mathrm{He}$ further observes that the reaction of the state to the objective of professions could depend on factors such as the "type of government in place, public expectations, and developmental requirements of the state, social relationships and the knowledge base of the profession."

The state institutions as actors in the system interpret and define direction for other stakeholders in the accounting environment. The enactment of the NASB Act , 2003 in Nigeria, is an evidence that state regulatory institutions actually have such roles. According to Post and Mahon (2000:400), regulatory institutions interpret and focus change in two different ways. One, it serves to stabilize the firm/body or institution against potential pressures for change from the public. Such a role provides the firm/ institutions operating in a particular industry with the opportunity to react to pressures for change. Two, the institution may be an agent of change especially where the leadership is desirous of effecting changes in the industry practices.

The state institutions are important in accounting practice discourse because they have been identified as key drivers of financial reporting outcomes. Studies by Fan and Wong, 2002; Leuz, Nanda and Wysocki, 2003 and Haw, Hwang and Wu, 2004, corroborate the assertion that institutions affect firms' actual reporting and disclosure practices, the accounting standards in force, notwithstanding. That institutions can impact accounting practice can be appreciated from the perception of North (1990), who defines institutions as the "humanly devised constraints that shape human interaction" that provide the "rules of the game in society." where rules govern the actions of players. He further observed that "though institutions could be inefficient sometimes, they exist primarily to curtail the opportunistic tendencies which could arise in an exchange relationship."

Notwithstanding the nature and quality of institutions in existence in a given financial reporting jurisdiction, three major criteria exist in assessing the quality of accounting practice (Owusu-Ansah and Yeoh 2005:33 and Afolabi, 2007:5). These criteria are relevant, reliable and comparable of information. Relevance (timeliness) and Reliability are relevant in determining the information that might be reported to ensure the depiction of an economic phenomenon is complete, neutral and free from material misstatement. It encompasses two requirements. First, financial reports ought to be prepared on the basis of sound accounting rules. Second, adequate steps should be taken to ensure the compliance with these rules (Simon and Taylor, 2002:45). Similarly, and in the opinion of FASB (2008) and IASB (2008), Comparability is the "quality of information that enables users to identify similarities and differences between sets of economic phenomena." Enhanced financial statement comparability is an outcome of compliance with regulations. Thus, the main gain of the enhanced comparability which flows from mandatory regulations, is greater crossborder investment (McCreevy 2005; 
Bielstein, Munter, and Schinas, 2007 and Tweedie, 2008).

\section{Hypothesis Development}

The study focused on the following institutions- The accountancy bodies in Nigeria (Institute of Chartered Accountants of Nigeria (ICAN) and the Association of National Accountants of Nigeria (ANAN), the Central Bank of Nigeria (CBN), Nigerian Accounting Standards Boards (NASB), National Insurance Commission (NAICOM), Security and Exchange Commission (SEC) and the Corporate Affairs Commission(CAC) in investigating the impact of state institutions on the quality of accounting practice. The reason for the focus on these institutions is that their provisions have implications for accounting and financial reporting practices of the regulated entities (World Bank, 2004).

\section{Accountancy Bodies (ICAN and ANAN)}

The Institute of Chartered Accountants of Nigeria (ICAN) and the Association of National Accountants of Nigeria (ANAN) are the two bodies responsible for the production of professional accountants in Nigeria. In this capacity, they ensure that members maintain high professional conduct required by stakeholders in discharging their professional and imperative duties. Therefore, a positive impact of the accounting bodies on the quality of accounting practice is expected.

\section{Central Bank of Nigeria (CBN)}

The banks and non-banking financial institutions are under the regulation of the Central Bank of Nigeria as the main statutory regulator. The regulation is as of the terms of the Banks and Other Financial Institutions Act, BOFIA (1991). The BOFIA contains provisions on financial reporting by banks. Banks are required under the Act to submit audited financial statements to the CBN for approval before publication. In line with these provisions, the impact of $\mathrm{CBN}$ on the quality of accounting practice is expected to be positive.

\section{Corporate Affairs Commission (CAC)}

Under the provisions of CAMA, the Corporate Affairs Commission has the power to regulate compliance with the financial reporting requirements in Nigeria. Listed companies in Nigeria, therefore, have it as a legal requirement to file a copy of their audited financial statements and directors' report with the Corporate Affairs Commission. Thus, the impact of CAC on the quality of accounting practice is posited to be positive.

\section{Securities and Exchange Commission (SEC)}

Under the Investment and Securities Act of 1999 and the Securities and Exchange Rules and Regulations (1999/2007), the Securities and Exchange Commission (SEC) and the Nigerian Stock Exchange (SE) regulate market participants. In that capacity, listed companies are required to file their audited financial statements with SEC and NSE before publication within three months after year-end. Listed companies are expected to comply fully with the relevant provisions, and thus, a positive impact of SEC on the quality of accounting practice is expected.

\section{National Insurance Commission (NAICOM)}

The audited financial statements of listed companies are expected to be submitted to the NAICOM within six months of year-end. This is because the NAICOM is charged with the administration and enforcement of the provisions of the Insurance Act under the National Insurance Act 2003. Based on its provisions with regard to accounting practice and with due compliance, a positive association of the impact of NAICOM on the quality of accounting practice is expected.

\section{Nigerian Accounting Standards Board (NASB)/Financial Reporting Council of Nigeria}


Before the Financial Reporting Council of Nigeria was established, the Nigerian Accounting Standards Board (NASB) was setting local accounting standards under the Nigerian Accounting Standards Board Act, 2003. Based on its mandate, it is required to influence accounting practice in Nigeria as the Act gave it the legal backing to enforce compliance with relevant standards. Consequently, a positive impact of the NASB on the quality of accounting practice in Nigeria is expected.

Based on the fore-going discussions, the following hypothesis is formulated for this study.

H1: State institutions have significant positive impact on the quality of accounting practice in Nigeria

\section{Research Method}

The survey research approach was adopted in the study and drew on the perception of stakeholders (compilers and users) of accounting information because it is the interpretation of stakeholders' expectations by institutions that forces changes in the core areas of professional practice (Post and Mahon, 2000; Mtigwe and Chikweche, 2008). The data were sourced using questionnaire administered to a total of 183 compilers (preparers) and two hundred and twenty five (225) users (represented by investment analyst). The copies of the questionnaire returned by the compilers were 75 out of which $38 \%$ representing (69) were useable. For the users, 43, representing $19 \%$ of the total copies of questionnaire returned were found useable.

\section{Measures}

The constructs (state institutions) were measured using purpose-developed multiitem indicators. To develop the measures/indicators, the enabling instruments of each of the institutions were first searched. In order to determine the relevant items for inclusion in the instrument, relevant and knowledgeable managers in the institutions were interviewed. A five-point Likert-type scale was used to measure all variables/constructs. We undertook series of steps to assess the validity of our measures in order to overcome potential measurement problems.

Particular attention was paid to the discriminate validity and reliability of each construct. In order to assess whether the multiple items represented a uni-dimensional scale, each section of the measurement instruments was factor analyzed. To ascertain the internal consistency of the indicators measuring a given construct, we also assessed the composite reliability of each of the constructs. The result of the Pearson correlation coefficients indicates that the variables correlate fairly well (between 0.436 and 0.695$)$. This means there is no perfect correlation among the variables since no correlation coefficient is greater than 0.9 . The implication is that there is no cause for concern with multicollinearity since the correlations among the exogenous variables (constructs) are not sufficiently high (Griffiths, Hill and Judge, 1993).

The individual item reliability (factor loading) and Composite reliability measured by Cronbach Alpha range between 0.808 and 0.876 . The threshold of 0.50 for individual reliability and 0.70 for composite reliability (Hulland, (1999) is not violated. Thus, there is a reasonable level of both discriminant and composite validity in our constructs.

\section{Model Formulation}

The model investigating the impact of state agencies on the quality of accounting practice in Nigeria is expressed as follows: 
$\mathrm{QAP}=\boldsymbol{\alpha}_{0}+\boldsymbol{\alpha}_{1} \mathrm{ACCTB}+\boldsymbol{\alpha}_{2} \mathrm{NASB}+\boldsymbol{\alpha}_{3} \mathrm{SEC}+\boldsymbol{\alpha}_{4} \mathrm{CBN}+\boldsymbol{\alpha}_{5} \mathrm{NAICOM}+\boldsymbol{\alpha}_{6} \mathrm{CAC}+\mathbf{u}_{\mathbf{1}}$ 1

The variables are as defined in the table below-

Table 2: Explanatory Variables and Predicted Signs

\begin{tabular}{|c|c|c|}
\hline Hypothesis & Predicted signs & Measure \\
\hline QAP & & $\begin{array}{l}\text { Measured by averaging three items which represent different } \\
\text { attributes of accounting quality-relevance (RELEV), reliability } \\
\text { (RELIAB) and comparability (COMPAR) }\end{array}$ \\
\hline АССТВ & $+\operatorname{sig}$ & $\begin{array}{l}\text { The impact is measured based on averaging six indicators as } \\
\text { defined in the ICAN Act } 1965 \text { and ANAN Act } 1993 \text {. }\end{array}$ \\
\hline NASB & $+\operatorname{sig}$ & $\begin{array}{l}\text { The average of seven items, relating to the powers and function of } \\
\text { NASB as defined in NASB Act } 2003 \text { is used. }\end{array}$ \\
\hline SEC & $+\operatorname{sig}$ & $\begin{array}{l}\text { Measurement based on the average of five indicators relating to } \\
\text { functions and powers conferred on SEC by Securities Act } \\
(1999 / 2007) \text {. }\end{array}$ \\
\hline $\mathrm{CBN}$ & $+\operatorname{sig}$ & $\begin{array}{l}\text { Measurement is by averaging five items contained in Banks and } \\
\text { Other Financial Institutions Act (1991). }\end{array}$ \\
\hline NAICOM & $+\operatorname{sig}$ & $\begin{array}{l}\text { This is measured based on the average of four indicators as } \\
\text { contained in the Insurance Act } 2003 \text {. }\end{array}$ \\
\hline CAC & $+\operatorname{sig}$ & $\begin{array}{l}\text { This is measured based on four indicators relating to the powers } \\
\text { and functions of the Registrar in the CAC as spelt out in CAMA, } \\
1990 \text {. }\end{array}$ \\
\hline
\end{tabular}

Equation (1) utilized the composite index of relevance, reliability and comparability as (QAP) using the pooled data (users' and compilers' responses). Equation (1) was used to test the hypotheses. Equation 1 is further decomposed and replicated as equations $2-4$ ( shown below) to capture the different elements of quality of accounting practice-Relevance (RELEV), Reliability (RELIAB) and Comparability (COMPAR) as dependent variables.

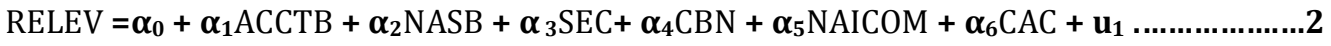

$$
\begin{aligned}
& \text { RELIAB }=\boldsymbol{\alpha}_{0}+\boldsymbol{\alpha}_{1} \mathrm{ACCTB}+\boldsymbol{\alpha}_{2} \mathrm{NASB}+\boldsymbol{\alpha}_{3} \mathrm{SEC}+\boldsymbol{\alpha}_{4} \mathrm{CBN}+\boldsymbol{\alpha}_{5} \mathrm{NAICOM}+\boldsymbol{\alpha}_{6} \mathrm{CAC}+\mathbf{u}_{1} \ldots \ldots \ldots \ldots \ldots . . . . . . . . . .3 \\
& \mathrm{COMPAR}=\boldsymbol{\alpha}_{0}+\boldsymbol{\alpha}_{1} \mathrm{ACCTB}+\boldsymbol{\alpha}_{2} \mathrm{NASB}+\boldsymbol{\alpha}_{3} \mathrm{SEC}+\boldsymbol{\alpha}_{4} \mathrm{CBN}+\boldsymbol{\alpha}_{5} \mathrm{NAICOM}+\boldsymbol{\alpha}_{6} \mathrm{CAC}+\mathbf{u}_{1} \ldots \ldots \ldots \ldots \ldots . . . . . . . .4
\end{aligned}
$$

\section{Results and Discussion}

\section{OLS Estimation}

Table 3: OLS Regression Results

\begin{tabular}{|l|l|l|l|l|}
\hline Variable & \multicolumn{4}{|c|}{ Equations } \\
\cline { 2 - 5 } & 1 (QAP) & 2 (RELEV) & 3 (RELIAB) & 4 (COMPAR \\
\cline { 2 - 5 } & Coefficient & Coefficient & Coefficient & Coefficient \\
\cline { 2 - 5 } & (t-statistic) & (t-statistic) & (t-statistic) & (t-statistic) \\
\cline { 2 - 5 } & P-value & P-value & P-value & P-value \\
\hline
\end{tabular}




\begin{tabular}{|c|c|c|c|c|}
\hline $\begin{array}{l}\text { ACCTB } \\
\text { (ICAN and ANAN) }\end{array}$ & $\begin{array}{l}0.306^{* * *} \\
(3.176) \\
0.002\end{array}$ & \begin{tabular}{|l}
0.151 \\
$(1.182)$ \\
0.239
\end{tabular} & $\begin{array}{l}0.476^{* * *} \\
(3.726) \\
0.000\end{array}$ & $\begin{array}{l}0.291^{* *} \\
(2.519) \\
0.013\end{array}$ \\
\hline NASB & $\begin{array}{l}0.511 \\
(1.303) \\
0.195\end{array}$ & \begin{tabular}{|l|}
$0.342^{* *}$ \\
$(2.237)$ \\
0.027
\end{tabular} & $\begin{array}{l}-0.072 \\
(-0.479) \\
0.640\end{array}$ & $\begin{array}{l}0.181 \\
(1.308) \\
0.193\end{array}$ \\
\hline SEC & $\begin{array}{l}-0.208^{*} \\
(-1.747) \\
0.083\end{array}$ & $\begin{array}{l}-0.330^{* *} \\
(-2.086) \\
0.039\end{array}$ & $\begin{array}{l}0.005 \\
(0.035) \\
0.972\end{array}$ & $\begin{array}{l}-0.301^{* *} \\
(-2.106) \\
0.037\end{array}$ \\
\hline$\overline{\text { CBN }}$ & $\begin{array}{l}0.220^{* *} \\
(2.035) \\
0.044\end{array}$ & $\begin{array}{l}0.358^{* *} \\
(2.498) \\
0.014\end{array}$ & $\begin{array}{l}0.114 \\
(0.792) \\
0.430\end{array}$ & $\begin{array}{l}0.189 \\
(1.454) \\
0.148\end{array}$ \\
\hline NAICOM & $\begin{array}{l}-0.092 \\
(-0.924) \\
0.357\end{array}$ & \begin{tabular}{|l|}
0.082 \\
$(0.622)$ \\
0.535
\end{tabular} & $\begin{array}{l}-0.249^{*} \\
(-1.886) \\
0.061\end{array}$ & $\begin{array}{l}-0.109 \\
(-0.912) \\
0.363\end{array}$ \\
\hline CAC & $\begin{array}{l}0.039 \\
(0.371) \\
0.711\end{array}$ & \begin{tabular}{|l}
-0.039 \\
$(-0.282)$ \\
0.778
\end{tabular} & $\begin{array}{l}0.207 \\
(1.483) \\
0.140\end{array}$ & $\begin{array}{l}-0.502 \\
(-0.309) \\
0.690\end{array}$ \\
\hline Constant & $\begin{array}{l}0.791^{* * *} \\
(2.369)\end{array}$ & $\begin{array}{l}0.482 \\
(1.212)\end{array}$ & $\begin{array}{l}0.743^{*} \\
1.868\end{array}$ & $\begin{array}{l}0.149^{* *} \\
3.198\end{array}$ \\
\hline $\begin{array}{l}\mathbf{R}^{2} \\
\mathbf{R}^{2} \text { adjusted } \\
\text { F-test } \\
\text { Std Error } \\
\text { P-value }\end{array}$ & $\begin{array}{l}0.353 \\
0.322 \\
530.260 \\
0.56474 \\
0.000\end{array}$ & \begin{tabular}{|l|}
0.313 \\
0.280 \\
9.514 \\
0.748 \\
0.000
\end{tabular} & $\begin{array}{l}0.238 \\
0.202 \\
6.525 \\
0.749 \\
0.000\end{array}$ & $\begin{array}{l}0.254 \\
0.218 \\
7.081 \\
0.671 \\
0.000\end{array}$ \\
\hline
\end{tabular}

\section{Note: Numbers in each cell are arranged in the following order- Coefficient, $t$-values (in parenthesis), p-values.}

The $\mathrm{F}$ statistic at $\mathrm{p}<0.001$ is significant in the four equations as $\mathrm{F}=530.260,9.514,6.525$ and 7.08 for equations $1,2,3$ and 4 respectively. This shows that the regressions have good fit.

The hypothesis predicts that there is significant positive impact of each of (ACCT, CBN, CAC, SEC, NAICOM and NASB) on the quality of accounting practice in Nigeria. In equation 1, which was used to test the hypothesis, the coefficients for ACCTB, and $\mathrm{CBN}$ are positive and significant, implying that both institutions contribute positively to the quality of accounting practice in Nigeria. This position is consistent with the hypothesis. NASB and CAC, though positive, are not significant. Both SEC and NAICOM have negative signs. Thus, the results for NASB, CAC, SEC and NAICOM are not consistent with the hypothesis. This position indicates that the provisions of NASB, CAC, SEC and NAICOM are not being enforced and complied with in the compilation of accounting information.

In terms of the quality of relevance (RELEV) of accounting practice, only two agencies have positive implications-NASB and CBN, while for reliability (REIAB) and comparability 
(COMPAR) only the Accounting bodies have positive implication for accounting practice. Except in terms of reliability, SEC has negative implication for accounting practice. The results also indicate that NAICOM has also not impacted accounting practice positively in Nigeria.

\section{Discussion}

This study has made contributions to our knowledge of the impact of state institutions on the quality of accounting practice in Nigeria. The impact of the professional accounting bodies is positive and highly significant. This could be ascribed to the strategies evolved in education and training, professional ethics and discipline of members and regular review of examination syllabus to take note of emerging issues in the profession. For instance, the professional accounting bodies engage in organizing Mandatory Continuing Professional Education Programmes for their members yearly. The bodies also actively participate in international seminars and trainings organized by bodies such as the International Federation of Accountants(IFAC) and other similar regional bodies of accountancy. The positive impact which the CBN has on the quality of accounting practice in Nigeria may be ascribed to the fact that the banking sector is highly regulated in Nigeria in line with the elaborate provisions in both the CBN Act and the BOFIA. The CAC is rated poorly. The result suggests that there is significant lapse in the enforcement of compliance with relevant rules and regulations. This may have been strengthened by the high level of corruption and poor record keeping by the Commission as earlier noted by the World Bank. The result, as it relates to SEC is consistent with the observation made by the World Bank (2004), that the SEC is ineffective in ensuring compliance with financial reporting requirements and enforcing sanctions against defaulters.

The impact of the NAICOM is negative though not significant. This suggests that the provisions of the Insurance Act are not being enforced by the Commission. This observation is supported by the Word Bank (2004) which noted that the Insurance Act under which the NAICOM operates does not adequately provide mechanisms to enforce compliance. The impact of the Nigerian Accounting Standards Board (NASB) is positive but not significant. The NASB itself operated without an enabling legal authority until the enactment of the NASB Act in 2003 although the standards issued by the NASB have statutory backing. Before the Act of 2003, compliance with accounting standards was not compelled by any instrument but based mainly on persuasion. However, after the Act was enacted, compliance became statutory with strict penalty for any default (see Sections 22-24, NASB, Act 2003).

\section{Conclusion}

The study was designed to ascertain the impact of state institutions on the quality of accounting practice in Nigeria. Though joint significance was observed and the level of impact differed among the institutions, the regression results support only two of the six hypotheses. That is, only two of the institutions-Professional accounting bodies (ICAN and ANAN) and the Central Bank of Nigeria (CBN) significantly and positively impact the quality of accounting practice in Nigeria. These findings provide empirical evidence that the current accounting regulations in Nigeria do not lead to significantly high transparent and better financial reporting. There is a need to streamline, codify and strengthen the requirements for financial reporting. This will assist to minimise inconsistencies in the provisions of the institutions with regard to financial reporting, remove the legion of bodies that review and approve financial statements before they are published. The regulatory bodies need to be strengthened in terms of capacity to ensure that their statutory provisions are adequately enforced with high level of commitment.

This study is subject to a number of limitations. First, only two groups of stakeholders (users and preparers of financial statements) were considered to the exclusion of others which include for instance, auditors and academic accountants. Second, while the study focused on only six institutions, there are 
other institutions whose provisions and activities could impact the quality of accounting practice in Nigeria. Following these limitations, future research might consider more stakeholders as well as more institutions in order to have more robust results.

\section{References}

1. Afolabi, F. (2007), Financial reporting in Nigerian emerging market. Paper presented at a seminar organized by the Morgan State University, Victoria, August.

2. Bielstein, M. M., Munter., P. H. and Schinas, W. J. (2007). How IFRS will affect financial reporting in the US. Published by KPMG's Department of Public Practice as part of the Defining Issues Series, New York.

3. Fan, J., and Wong, T. (2002), Corporate ownership structure and the in formativeness of accounting earnings in East Asia. Journal of Accounting and Economics, 10, 1-30.

4. Financial Accounting Standards Board (2008). Concepts statement 6: Reconsideration interpretation46(R)

5. Griffiths, W. E., Hill R. C. and Judge, G. C. (1993). Learning and Practicing Econometrics, John Wiley.

6. Haw, I. B., Hwang, L., Wu, W. (2004). Ultimate ownership, income measurement and legal and extral-legal institutions. Journal of Accounting Research, 42, 423-462.

7. Hulland, J. (1999). Use of partial least square in strategic management research. A review of four recent studies. Strategic Management Journal, 20 (2), 195-204.

8. International Accounting Standards Board (2008). Exposure draft of an improved conceptual framework for financial reporting.

9. Iyoha,F.O and Jimoh, J. (2011). Institutional Infrastructure and the Adoption of International Financial Reporting Standards (IFRS) in Nigeria. School of Doctoral Studies (European Union) Journal. 3(17-24).

10. Leuz, C, Nanda, D. and Wysocki, P. (2003), Earnings management and investor protection: An international comparison. Journal of Financial Economics, 69, 505-527.

11. McCreevy, C. (2005). IFRS-No pain, no gain? Speech to the Federation de Experts Compatables Europeans, Brussels, October 18.

12. Mtigwe, B. \& Chikweche, T. (2008). Developing country perspectives on country of- origin effects: The case of the proudly South African campaign. Journal of African Business, 9(1), 77-92.

13. North, D. (1990). Institutions, institutional change and economic performance. Cambridge, UK; Cambridge University Press.

14. Okike, N. (2004). Management of crisis: the response of the auditing profession in Nigeria to the challenges to its legitimacy. Accounting, Auditing \& Accountability Journal, 17(5), 705-729.

15. Owusu-Ansah, S \& Yeoh, J (2005). The effect of legislation on corporate disclosure practices, Abacus, 41(1), 1-19.

16. Post, J. E. and Mahon, J. F. (2000), Articulated turbulence: The effect of regulatory agencies on corporate response to social change. Academy of management Review, 5(3), 399-407.

17. Simon, D.T. and Taylor. M.(2002). The market for audit services in Nigeria. Research in Accounting in Emerging Economies. London. Elsevier.

18. Spiceland, J.D, J.F. Sepe and L.A. Tomassini (2001). Intermediate Accounting. New York. McGraw-Hill.

19. Tweedie, D. (2008). Prepared statement of Sir David Tweedie, Chairman of the 
International Accounting Standards Board to officials of the Singaporean government. Retrieved July 82008 from http://www.asc.gov.sg/attachments/IFRS17J ul08_IASB_World
20. Uche, U.U. (2002). Professional accounting development in Nigeria: threats from the inside and outside. Accounting, Organization and Society, 27, 472-496. 